
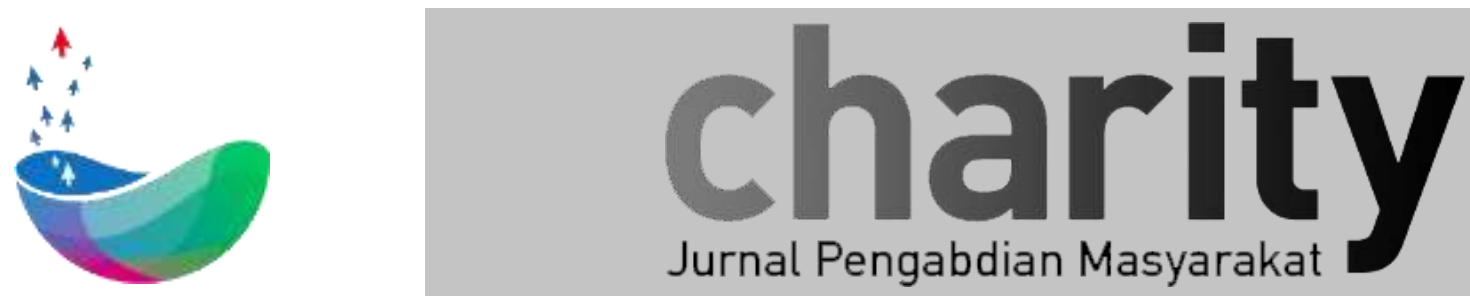

\title{
PROGRAM PEMBANGUNAN KESEHATAN MASYARAKAT BERBASIS DIGITAL DI DAERAH PESISIR KECAMATAN PALABUHANRATU TAHUN 2017
}

\author{
Tris Eryando ${ }^{1}$, Eddy Afriansyah ${ }^{2}$, Dewi Susanna $^{3}$, Dian Wulandari ${ }^{4}$, Tri Agustini ${ }^{5}$ \\ ${ }^{1}$ Departemen Biostatistika dan Ilmu Kependudukan, Fakultas Kesehatan Masyarakat, UI \\ ${ }^{2}$ Unit Informasi Teknologi, Fakultas Kesehatan Masyarakat, UI \\ ${ }^{3}$ Departemen Kesehatan Lingkungan, Fakultas Kesehatan Masyarakat, UI \\ ${ }^{4}$ Unit Riset dan Pengabdian Masyarakat, Fakultas Kesehatan Masyarakat, UI \\ ${ }^{5}$ Desa Binaan, Fakultas Kesehatan Masyarakat, UI \\ *tris.eryando@gmail.com
}

\section{INFO ARTIKEL}

Diterima 30 Oktober 2017

Direvisi 7 November 2017

Disetujui 16 November 2017

Tersedia Online 24 Oktober 2018
Keyword : kesehatan masyarakat, registrasi vital, pesan kesehatan, sistem informasi

\begin{abstract}
ABSTRAK
Pengembangan masyarakat adalah upaya yang harus dilakukan untuk meningkatkan kualitas kehidupan masyarakat, hal ini menjadi tanggung jawab bersama dari berbagai elemen. Pemberdayaan masyarakat dilakukan di daerah pesisir Kecamatan Palabuhanratu dengan pendekatan pembangunan kesehatan masyarakat berbasis digital. Dengan bantuan sistem informasi berbasis digital di bidang kesehatan akan cepat diketahui tren penyakit disuatu wilayah, perkembangan gizi buruk di suatu daerah, komposisi penduduk berdasarkan usia dan sebagainya. Sehingga informasi yang update ini mempermudah penentuan intervensi apa yang akan dilakukan oleh pemerintah daerah. Tujuan dari kegiatan ini adalah untuk memanfaatkan ICT dalam meningkatkan derajat kesehatan masyarakat. [1]

Menggunakan metode pengumpulan data berupa kuesioner dan observasi sehingga tersusunlah rencana kegiatan berupa pelatihan, edukasi, konsultasi dan advokasi. Kegiatan pelatihan fokus kepada pelatihan registrasi vital untuk pejabat desa dan SIMPUSTU untuk bidan desa serta edukasi dan konsultasi berfokus pada kegiatan SMS Gateway berupa pengiriman pesan kesehatan. Hasil akhir dari kegiatan ini adalah adanya peningkatan kesadaran dan pengetahuan masyarakat terkait kesehatan sehingga derajat kesehatan masyarakat Kecamatan Palabuhanratu dapat meningkat. Hambatan yang dihadapi adalah masyarakat yang belum terbiasa membuat laporan terkait kependudukan dan kesehatan menggunakan komputer sehingga diperlukan adanya edukasi tambahan agar masyarakat menjadi terbiasa.
\end{abstract}

Korespondensi :

Direktorat Penelitian dan Pengabdian Masyarakat, Universitas Telkom

Jl. Telekomunikasi No. 1, Terusan Buah Batu, Bandung, 40257

Indonesia.

E-mail: charity@telkomuniversity.ac.id

ORCID ID:

Penulis Pertama: -

https://doi.org/10.25124/charity.v1i01.1572

Paper_reg_number Charity0001010101 @ The Authors. Published by Directorate of Research and Community

Service, Telkom University.

This is an open access article under the CC BY-NC 4.0 license (https://creativecommons.org/licenses/by-nc/4.0/) 


\section{PENDAhUluan}

Indeks Pembangunan Manusia (IPM) digunakan untuk mengukur capaian pembangunan manusia berbasis sejumlah komponen dasar kualitas hidup. IPM dibangun melalui 3 indeks komponen pembentuknya, yaitu indeks pendidikan, indeks standar hidup layak, dan indeks kesehatan. Rata-rata IPM Indonesia tahun 2016 sebesar 70.18. Terdapat beberapa prov insi di Indonesia dengan IPM lebih rendah dari Indonesia, salah satunya adalah Provinsi Jawa Barat. Pada tahun 2016, IPM Provinsi Jawa Barat sebesar 70.05 dan IPM Kabupaten Sukabumi sebesar 65.13 (Badan Pusat Statistik, 2017).

Kecamatan Palabuhanratu merupakan salah satu kecamatan dari Kabupaten Sukabumi yang memiliki sepuluh desa/kelurahan yang diantaranya terdapat tiga daerah yang termasuk ke dalam area pesisir, yaitu Desa Citarik, Kelurahan Palabuhanratu, dan Desa Citepus. Luas wilayah sebesar $8260 \mathrm{Ha}$, sebagian besar wilayah di Kecamatan Palabuhanratu adalah untuk pertanian. Mayoritas penduduk kecamatan ini adalah bertani dan nelayan. Terdapat 26 kasus kasus penderita gizi buruk dan penerima kartu askeskin 54739 orang (Badan Pusat Statistik Kabupaten Sukabumi, 2017).

Pengembangan Masyarakat (Community Development) itu sendiri adalah upaya meningkatkan kualitas masyarakat sehingga mampu mengejar ketertinggalan dalam berbagai bidang kehidupan. Secara normatif, pengembangan masyarakat meliputi pengembangan kualitas sumber daya manusia, kesehatan, dan pertumbuhan ekonomi. Pengembangan masyarakat merupakan proses. Oleh karena itu, masyarakat dibantu mengorganisasi sendiri sejak perencanaan sampai pelaksanaan sehingga masyarakat dapat merencanakan sesuai kebutuhan, menyelesaikan persoalan dengan memanfaatkan secara optimal sumber daya yang ada. Jika diperlukan, mencarikan sumber daya lain sebagai suplemen dari institusi di luar komunitas mereka, baik pemerintah maupun institusi masyarakat lainnya.

Pemanfaatan teknologi informasi dan komunikasi dalam bidang kesehatan masyarakat merupakan media yang sangat penting. Dengan memanfaatkan sistem informasi dan komunikasi, kegiatan seperti perilaku hidup bersih dan sehat (PHBS), pemantauan gizi pada balita, perkembangan trend penyakit di puskesmas, pendataan penduduk berdasarkan kelompok usia dan lain sebagainya akan sangat terbantu bila pendataan tersebut menggunakan sistem informasi berbasis digital. Dengan bantuan sistem informasi berbasis digital di bidang kesehatan kita akan cepat mengetahui tren penyakit disuatu wilayah, perkembangan gizi buruk di suatu daerah, komposisi penduduk berdasarkan usia dan sebagainya. Sehingga informasi yang update ini akan mempercepat intervensi apa yang akan dilakukan oleh pemerintah daerah di wilayah tersebut. Tujuan dari kegiatan ini adalah untuk memanfaatkan ICT dalam meningkatkan derajat kesehatan masyarakat dan meningkatkan kualitas sumber daya manusia dan kesehatan.

\section{MASALAH}

Kawasan Palabuhanratu telah menjadi daerah wisata terkenal dan menjadi tujuan utama wisatawan di saat hari libur. Walaupun sudah menjadi tempat wisata masih terdapat permasalahan berupa belum efektifnya pengelolaan dan pelayanan tempat wisata yang berakibat kepada masyarakat sekitar. Nelayan kecil masih belum diperhatikan dan kurang mendapat bantuan modal serta terdapat perbedaan yang signifikan antara nelayan trandisional dengan nelayan rumpon. Apabila wilayah pesisir Palabuhanratu lebih dioptimalkan kemungkinan masyarakat pesisir dapat hidup lebih sejahtera karena memiliki potensi SDA yang melimpah.

Kawasan ini walaupun memiliki daerah pesisir yang luas, akan tetapi masih banyak kejadian gizi buruk seharusnya asupan gizi masyarakat dapat terpenuhi dari hasil perikanan maupun hasil pertanian. Hal ini terjadi karena kebanyakan lahan pertanian di kawasan tersebut 
bukan lagi milik sendiri, tetapi sudah menjadi milik orang lain dan warga sekitar hanya sebagai buruh.

Permasalahan kesehatan lainnya adalah Palabuhanratu sebagai salah satu dari 11 daerah endemis malaria di Kabupaten Sukabumi (Wigati, Ariati, Y, Andris, H, 2010). Malaria adalah penyakit yang ditularkan oleh nyamuk genus Anopheles dengan faktor lingkungan yang mendukung perkembangan penyakit malaria adalah sistem pengaturan air yang buruk, kondisi perumahan yang tidak layak, penebangan hutan dan menurunnya keanekaragaman hayati (WHO dalam Wigati, 2010). Topografi wilayah Palabuhanratu merupakan daerah pantai dengan hembusan angin yang cukup kencang membuat hal ini menjadi poin yang harus diperhatikan.

\section{METODE PELAKSANAAN}

\subsection{Metode Pelaksanaan Kegiatan Pengabdian}

Program pembangunan kesehatan masyarakat berbasis digital dilaksanakan dengan menggunakan metode berbentuk pelatihan, konsultasi, dan advokasi. Pelatihan adalah sebagai langkah pertama dalam kegiatan pengabdian masyarakat ini, bertujuan untuk memperkenalkan aplikasi yang telah dibuat yang disesuaikan dengan kebutuhan masyarakat serta melakukan transfer pengetahuan terkait penggunaan aplikasi sehingga aplikasi ini dapat digunakan dengan baik. Kegiatan ini diharapkan dapat menambah kemampuan dan membuat masyarakat menjadi lebih 'melek' terhadap teknologi. Pelatihan registrasi vital dilakukan di Balai Desa dengan target utama adalah pejabat desa sedangkan untuk SIMPUSTU dilakukan di Puskesmas Pembantu dengan sasaran bidan desa.

Konsultasi bertujuan memberikan ruang kepada masyarakat untuk bertanya apabila terdapat kesulitan dalam penggunaan aplikasi dan dapat bertanya dengan bebas terkait kesehatan dengan membalas pesan kesehatan yang telah disebar ke seluruh masyarakat. SMS Gateway 'Pesan Kesehatan' dikembangkan dengan sistem dapat menerima balasan dari masyarakat. Jika masyarakat memiliki pertanyaan dapat secara langsung mendapatkan jawaban dari admin SMS Gateway.

Advokasi adalah langkah lanjutan yang dilakukan setelah data-data terkumpul. Datadata yang telah dikumpulkan dari registrasi vital maupun SIMPUSTU dapat dijadikan sebagai bahan advokasi kepada pemerintah daerah terkait kondisi kesehatan daerah tersebut.

\subsection{Teknik Pengumpulan Data}

Pengumpulan data dilakukan dengan teknik pengambilan data berupa pertanyaan kuesioner dan observasi

\subsection{Teknik Analisis Data}

Teknik analisis data yang dilakukan adalah deskriptif kuantitatif, bertujuan untuk mendapatkan gambaran karakteristik penduduk dan kondisi kesehatan penduduk.

\subsection{Lokasi, Waktu, dan Durasi Kegiatan}

Kegiatan akan dilaksanakan di daerah pesisir di Kecamatan Palabuhanratu, Kabupaten Sukabumi, Jawa Barat di tahun 2017.

\section{ANALISA HASIL KEGIATAN}

Kegiatan-kegiatan yang akan diajukan untuk dilakukan di Kecamatan Palabuhanratu, Kabupaten Sukabumi, Jawa Barat adalah kegiatan-kegiatan yang sudah pernah dilakukan di daerah pesisir pantai utara Jawa Barat, yaitu Desa Sedari Kabupaten Karawang. Kegiatan ini merupakan adaptasi dari kegiatan yang sama, tetapi dilakukan di tempat berbeda. Analisa 
kegiatan yang dilakukan adalah hasil kegiatan yang pernah terlaksana di Desa Sedari, Kabupaten Karawang.

\subsection{Kegiatan Penggunaan Aplikasi Registrasi Vital}

Sistem registrasi telah dikenal sejak lama. Pengumpulan data-data mengenai peristiwaperistiwa penting menyangkut kelahiran seperti akte kelahiran, kematian, perkawinan, perceraian, adopsi, migrasi, dan sebagainnya. Singkatnya registrasi vital meliputi semua member data sejarah yang tercatat dengan resmi baik oleh pemerintah atau badan swasta lainnya. Kelebihan dari sistem registrasi adalah data bertahan lama dan gampang diperoleh kapan saja dibutuhkan.

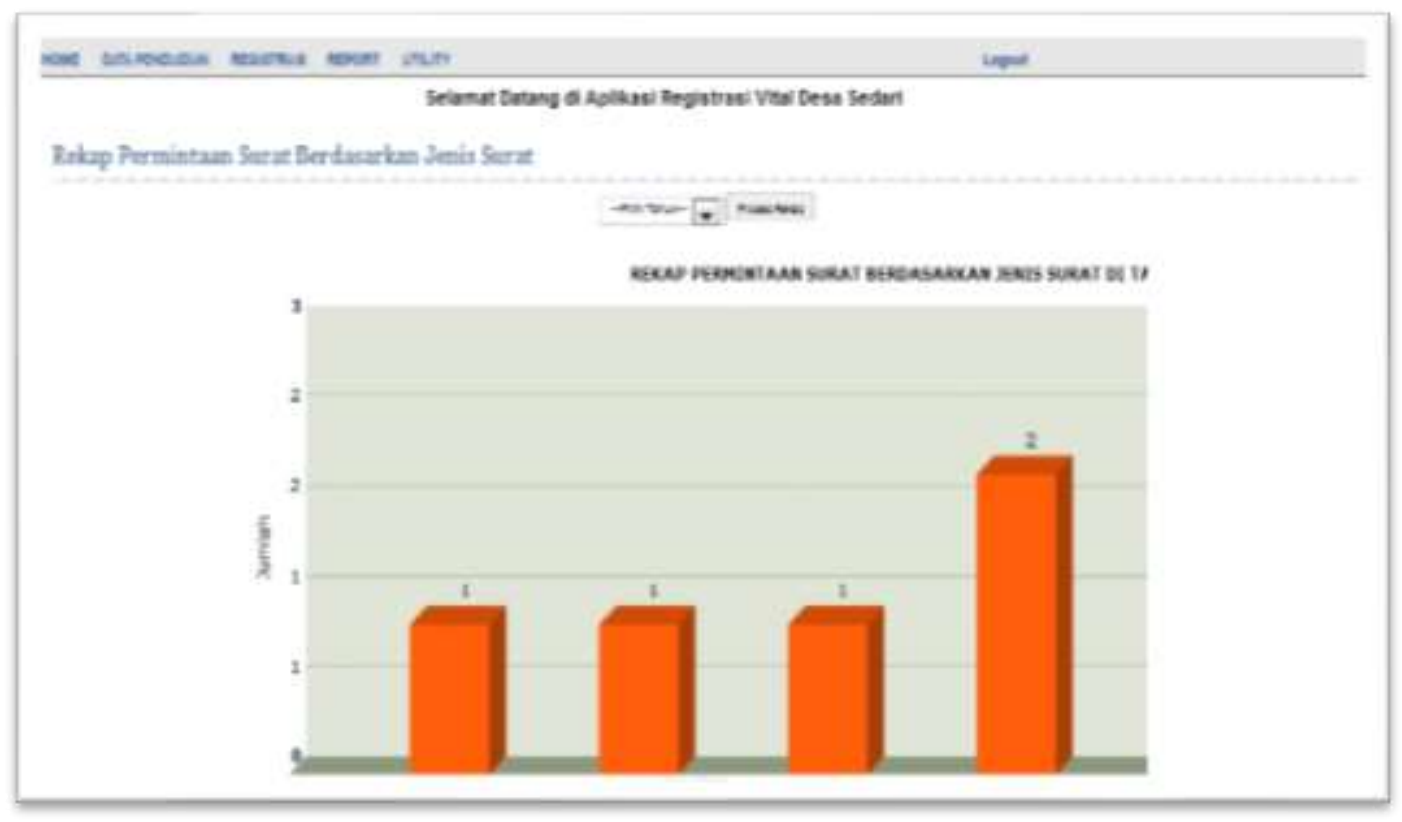

Gambar 1 Tampilan Laporan Aplikasi Registrasi Vital

Penggunaan aplikasi registrasi vital untuk pencatatan kegiatan kependudukan di kantor desa sampai saat ini masih minim. Hal ini sebabkan beberapa faktor yaitu belum terbiasanya petugas pencatatan kependudukan untuk menggunakan aplikasi berbasis komputer. Petugas lebih terbiasa mencatat langsung (tulis tangan) dan rekap dengan menggunakan Microsoft Excel. Untuk mengatasi kendala tersebut akhirnya petugas desa cukup memasukan data kegiatan kependudukan melalui Microsoft Excel kemudian data file excel tersebut selanjutnya di email ke FKMUI. Data-data yang di-email ini nantinya bisa diolah lebih lanjut untuk mengeluarkan laporan terkait registrasi kependudukan di desa masing-masing. Kegiatan revitalisasi statistik vital terpusat pada pencatatan identitas seluruh penduduk di Kecamatan Palabuhanratu, Kabupaten Sukabumi. Hasil dari pencatatan tersebut kemudian digunakan untuk pengembangan database statistik vital dan pembuatan KTP yang bekerja sama dengan pemerintah daerah serta sertifikat kelahiran untuk seluruh bayi di Kecamatan Palabuhanratu, Kabupaten Sukabumi. 


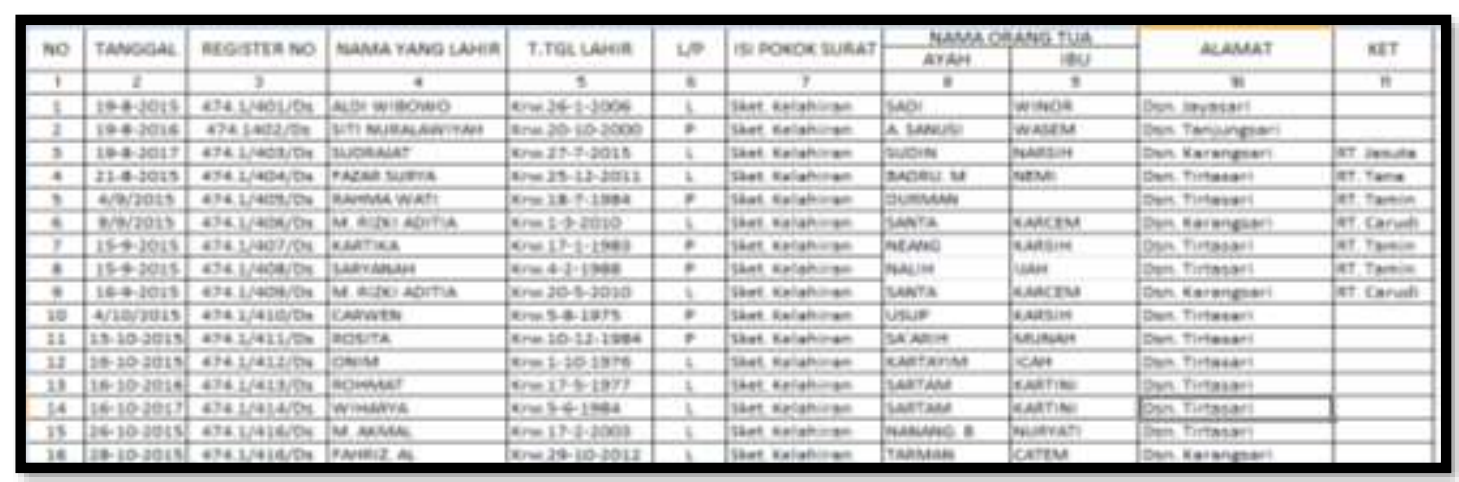

Gambar 2 Tampilan Registrasi Kelahiran

\begin{tabular}{|c|c|c|c|c|}
\hline \multicolumn{5}{|c|}{$\begin{array}{l}\text { MEGISTRASI SURAT KELUAR DESA SEDARI } \\
\text { TAHUN } 2015\end{array}$} \\
\hline \multicolumn{5}{|c|}{ SURAT KELUAAR } \\
\hline \multicolumn{2}{|c|}{ SUFAT } & \multirow{2}{*}{ TANCGAL DIKaHMM } & \multirow{2}{*}{ TUIUAN SURAT } & \multirow{2}{*}{ PERIRAL } \\
\hline NOMOR & TANOGAL & & & \\
\hline 474/37/Desa & $8 / 3 / 2013$ & $4 / 2 / 2015$ & Camat Cibuaya & Laporan Porkombangan Ponduduk Deal Sedari Periode juli 2015 \\
\hline $474 / 30 / 0$ esa & $8 / 4 / 2015$ & $8 / 3 / 2015$ & Camat Cobuaya & \\
\hline $147,251 / 29 / \mathrm{Ds}$ & 8/7/2015 & B/7/2015 & Bupati Karawang & PEKMOHONAN PENCAIHAN DANA DESA TAHAO 1 (satU) \\
\hline 474,4/40/Ds. & $8 / 7 / 2015$ & $8 / 13 / 2015$ & Camat coboaya & Daftar namia \& no, Hp aparatur Desa Sedan \\
\hline $691 / 41 / \mathrm{Ds}$ & $8 / 8 / 2015$ & $8 / 12 / 2015$ & Dinas Pergairan Kec Tirta aya & Dermohonan ijin pengambilan air ingasi \\
\hline $620 / 42 / D_{s}$ & $8 / 14 / 2015$ & $1 / 24 / 2015$ & Bupati Karawang Dines Cipto Karya & Surat Permohomin Rekomendosi EUTILAHU \\
\hline $630 / 45 / D S$ & $8 / 16 / 2015$ & $8 / 21 / 2015$ & Dinas PKP Kab. Karawane & Dengalihan pembanqua an jembatan Dsn. Neglvsari \\
\hline $400 / 40 / 0 s$ & $27-8.2015$ & & Pit Bupati knw. & Laporan oll speel dipantat sedari \\
\hline $511 / 47 / 05$ & 27.8 .2015 & $27-8-2015$ & Ka. Sub drive bulof Kab. kne & Denfajuar fUASKIN alokasi bih agust \\
\hline $511 / 42 / \mathrm{Ds}$. & $8 / 29 / 2015$ & $4 / 9 / 2015$ & Ka. Sub drive bulog Kab, Krww & Pengrajuan haSkiN alokasi bulan juit \\
\hline $620 / A 9 / 0 s$ & $\mathrm{~A} / 30 / 2015$ & & PIr Bupati Krw, Dinas Bina marge & Permohonan peningkatan jalan poros Desa (perterasun) T.sari \\
\hline
\end{tabular}

Gambar 3 Tampilan Registrasi Surat

\begin{tabular}{|c|c|c|c|c|c|c|c|c|c|}
\hline \multicolumn{10}{|c|}{ REGISTRASI SURAT KETERANGAN DESA } \\
\hline \multicolumn{10}{|c|}{ TAHUN 2015} \\
\hline NO & TANGGAL & NOSURAT & NAMA & LP & T. TGLLAHIR & PEKERIAAN & PENDIDIKAN & ALAMAT & KEPERLUAN \\
\hline 1 & 2 & 3 & 4 & 5 & 6 & 7 & 8 & 9 & 10 \\
\hline 1 & $8 / 7 / 2015$ & $474 / 1 / D s$ & PUII LESTARI & $p$ & KRW.10-5-1994 & & SLTP & Dsn. Tirtasari Rt03/01 & Melamar Kerja \\
\hline 2 & $8 / 8 / 2015$ & $474 / 2 / \mathrm{Ds}$ & SALAM SUGITO & $\mathrm{L}$ & KRW.16-4-1996 & & SLTA & Dsn. Karangsari Rt 01/02 & Melamar Kerja \\
\hline 3 & $8 / 9 / 2015$ & $474 / 3 / \mathrm{Ds}$ & FERA TRISTIA & $\mathrm{p}$ & KRW.8-4-1982 & MRT & SD & Dsn. Tanjungsari & Melamar Kerja \\
\hline 4 & $8 / 10 / 2015$ & $474 / 4 / \mathrm{Ds}$ & RAHMATULAH & $\mathrm{L}$ & KRW.17-5-1981 & Buruh & SLTA & Dsn. Jayasari & Melamar Kerja \\
\hline 5 & $1 / 10 / 2015$ & $474 / 5 / D S$ & CARWEN & L & KRW.5-8-1975 & MRT & SD & Dsn. Tirtasari & Administrasi TKC \\
\hline 6 & $6 / 10 / 2015$ & $474 / 6 / \mathrm{Ds}$ & HENDRA KUSUMAYADI & L & KRW.14-8-1982 & Buruh & SLTA & Dsn. Tirtasari & Pem. Listrik \\
\hline 7 & $7 / 10 / 2015$ & $474 / 7 / D S$ & JAMAL & L & KRW.10-4-1992 & Buruh & SLTP & Dsn. Karangsari & Melamar Kerja \\
\hline 8 & $10 / 10 / 2015$ & $474 / 8 / \mathrm{Ds}$ & ANGGI PITRIANI & $p$ & KRW.4-7-1996 & Buruh & SLTP & Ds. Neglasari & Melamar Kerja \\
\hline 9 & $22 / 10 / 2015$ & $474 / 9 / D s$ & SITI NUROHMAH & $\mathrm{p}$ & KRW.2-8-1999 & Buruh & SLTP & Dsn. Jayasari & Melamar Kerja \\
\hline 10 & & & & & & & & & \\
\hline
\end{tabular}

Gambar 4 Tampilan Registrasi Surat Keterangan Desa

\subsection{Penggunaan Aplikasi SIMPUSTU}

Aplikasi Simpustu yang sudah diinstal dan difasilitasi notebook untuk pengelolaan data kunjungan pasien di Puskesmas Pembatu Desa ditujukan untuk memudahkan dalam pencatatan dan merekap data rutin baik bulanan, semester maupun tahunan. Tentunya penggunaan aplikasi ini akan dirasa manfaatnya setelah berjalan minimal satu tahun dan aplikasi simpustu ini menjadi rujukan/acuan dalam menghasilkan informasi berupa laporan/ rekap data terkait kujungan pasien. 


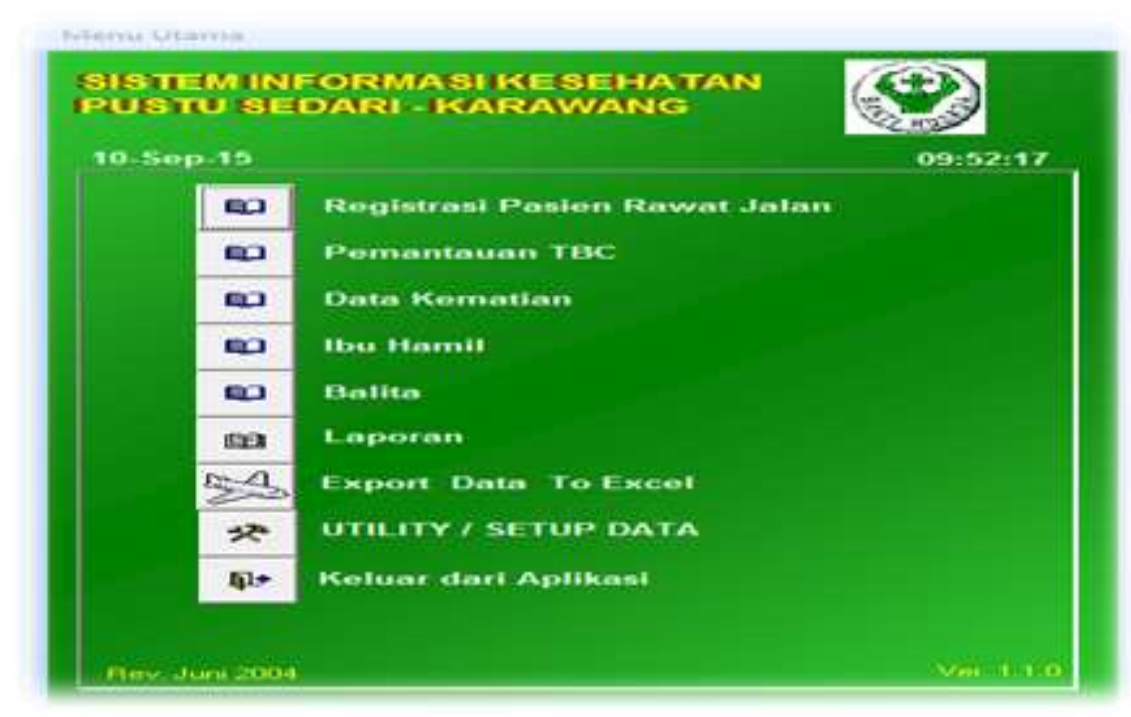

Gambar 5. Tampilan menu Aplikasi SIMPUSTU

Kendala dalam penggunaan aplikasi Simpustu di desa Sedari adalah terbatasnya SDM yang intens untuk memasukan data kunjungan kedalam aplikasi Simpustu. Untuk mengatasi kendala tersebut maka proses rekap data kunjungan rutin dilakukan dengan bantuan Microsoft Excel. Data kunjungan pasien yang sudah input ini selanjutnya dikirim ke FKM melalui email.

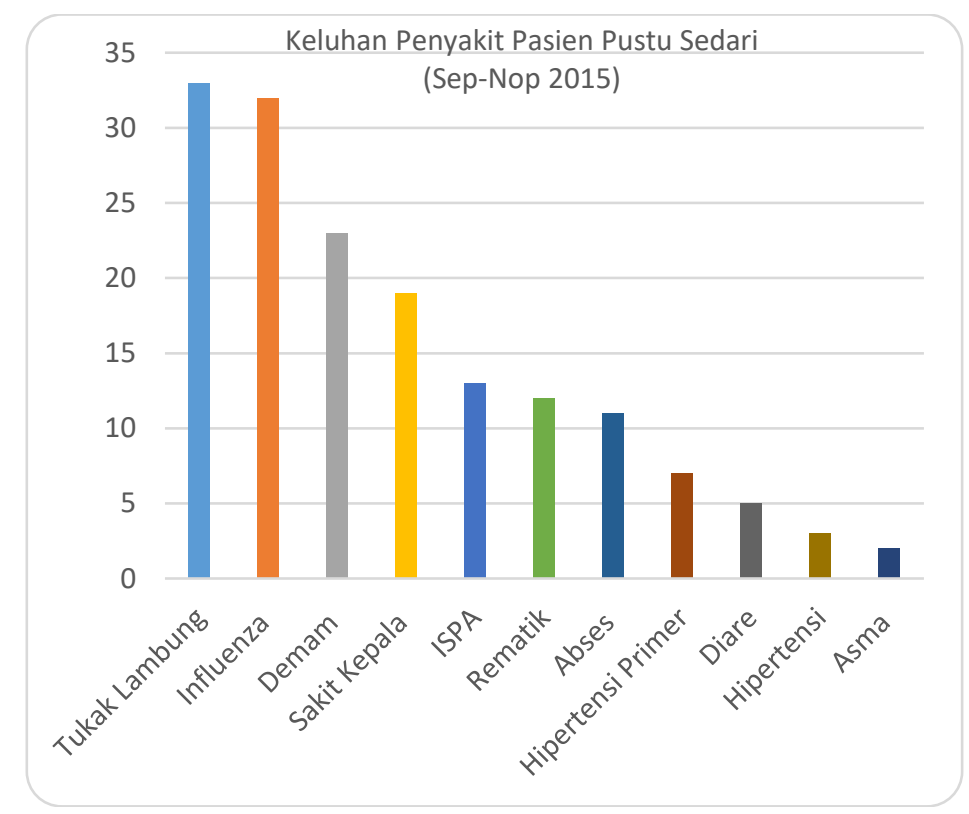

Gambar 6. Grafik keluhan penyakit pasien Pustu Sedari

\subsection{SMS Gateway 'Pesan Kesehatan'}

Pesan kesehatan yang dikirim ke penduduk Sedari (kader, kepala dusun, aparat desa, tokoh masyarakat) merupakan sarana untuk menyampaikan pesan-pesan kesehatan yang efektif dan efisien. Efektif karena pesan yang dikirim langsung diterima oleh warga Sedari ke handpone penduduk dengan cepat dan efisien karena biaya SMS pesan kesehatan yang dikirim relatif murah (Rp 120/sms). SMS Gateway Pesan kesehatan juga menjadi sarana komunikasi yang efektif antara FKMUI dengan penduduk desa terkait dengan masalah kesehatan. Setiap pesan kesehatan yang dikirim ke penduduk desa Sedari berisi pesan yang biasa dialami penduduk desa seperti pencegahan diare, perilaku hidup sehat dan bersih, kesehatan 
lingkungan dan sebagainya. Penduduk desa Sedari juga bisa mengirim SMS balasan untuk menanyakan lebih detail lagi terkait SMS pesan kesehatan yang diterima.

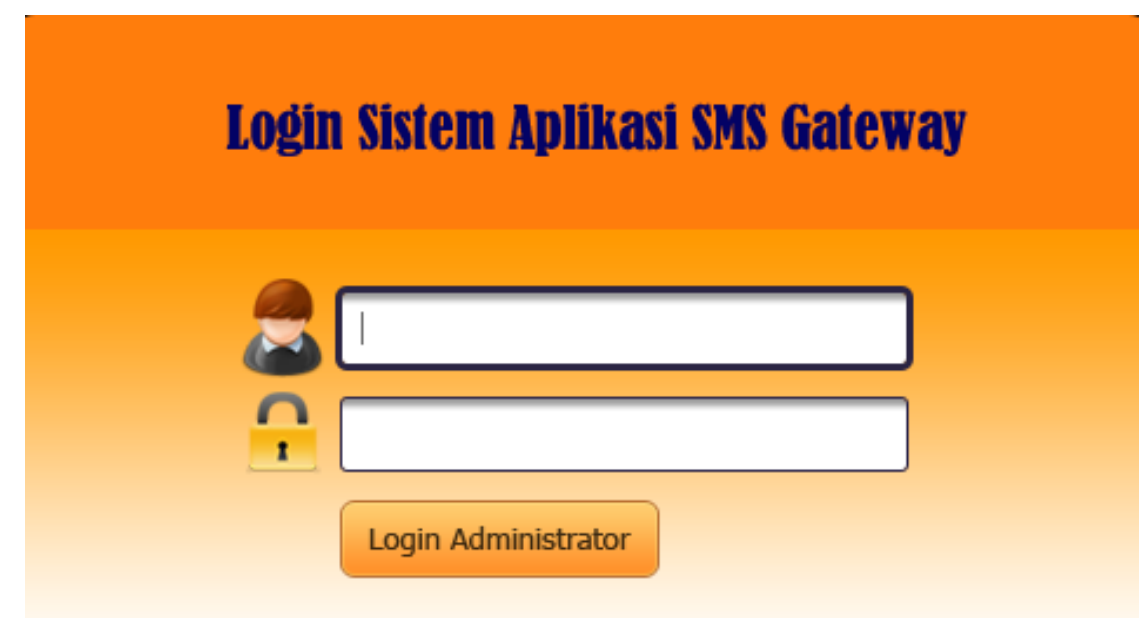

Gambar 7. Tampilan login system SMS gateway

Berikut adalah data-data yang bisa didapatkan dari aplikasi SMS Gateway, yaitu:

- Rekapitulasi pengiriman pesan kesehatan

- Rekapitulasi pesan kesehatan dengan jumlah penerima

- Rekapitulasi SMS masuk yang dikirim oleh warga



Gambar 8. Tampilan SMS masuk



omperan Bnts:

Gambar 9. Tampilan saat pengiriman SMS pesan kesehatan 
Berikut adalah beberapa contoh pesan kesehatan yang dikirimkan kepada warga:

- Matikan rokok anda sekarang sebelum rokok mematikan anda dan orang di sekitar anda

- Stop menambah beban bumi dengan sampah

- Cermati konsumsi GGL (Gula, Garam, Lemak) untuk jantung sehat anda!

- Punya Balita? Rutin ke Posyandu yaa..

- Setia pada pasangan, lindungi keluarga dari HIV AIDS

\section{KESIMPULAN DAN SARAN}

Teknologi untuk masyarakat harus terus dikembangkan seiring dengan perkembangan zaman dan kebutuhan masyarakat. Masyarakat harus diperkenalkan dengan teknologi dan berbagai aplikasi yang dapat mempermudah kehidupan. Kecamatan Palabuhanratu, Kabupaten Sukabumi adalah daerah yang memiliki potensi yang sangat besar, dengan adanya pantai-pantai indah yang menjadi daya tarik membuat daerah ini sangat terkenal dan banyak wisatawan yang berkunjung. Akses kesehatan juga tetap harus menjadi perhatian utama dari daerah ini, karena terdapat ketimpangan sosial akibat berkembangnya wisata di daerah ini. Simpulan dari kegiatan yang telah dilaksanakan tercantum dalam tabel di bawah ini:

Table 1. Simpulan Pelaksanaan Kegiatan

\begin{tabular}{|c|c|c|c|c|c|c|}
\hline Kegiatan & Indikator & $\begin{array}{l}\text { Target/ } \\
\text { Sasaran }\end{array}$ & $\begin{array}{c}\text { HASIL } \\
\text { PENCAPAIAN } \\
\text { PER Q1/2016 }\end{array}$ & Evidence & $\begin{array}{c}\text { Kendala } \\
\text { dan } \\
\text { Hambatan }\end{array}$ & $\begin{array}{l}\text { Solusi/next } \\
\text { plan }\end{array}$ \\
\hline $\begin{array}{l}\text { A. } \\
\text { SIMPUSTU } \\
\text { (Sistem } \\
\text { Pencatatan } \\
\text { dan } \\
\text { Pelaporan } \\
\text { Puskesmas } \\
\text { Pembantu) }\end{array}$ & $\begin{array}{l}\text { Data status } \\
\text { kesehatan } \\
\text { masyarakat } \\
\text { Desa Sedari } \\
\text { periode } \\
\text { 2015- 2016 }\end{array}$ & $\begin{array}{l}\text { Pelaporan } \\
\text { dan } \\
\text { pencatatan } \\
(1 \\
\text { worksheet) } \\
\text { selama } \\
\text { periode } \\
\text { Tahun } \\
2015-2016 \\
\end{array}$ & $\begin{array}{l}\text { September } 2015 \\
\text { sd Februari } \\
2016\end{array}$ & $\begin{array}{l}\text { Rekap Data } \\
\text { Nop } 15 \mathrm{sd} \\
\text { Mar } 16\end{array}$ & $\begin{array}{l}\text { pengiriman } \\
\text { rekap data } \\
\text { dari bidan } \\
\text { desa }\end{array}$ & $\begin{array}{l}\text { Peningkatan } \\
\text { kemampuan } \\
\text { pengolahan } \\
\text { data dengan } \\
\text { Komputer }\end{array}$ \\
\hline $\begin{array}{l}\text { B. } \\
\text { Registrasi } \\
\text { Vital (Surat } \\
\text { ket.lahir, } \\
\text { mati, } \\
\text { kawin, } \\
\text { cerai) }\end{array}$ & $\begin{array}{l}\text { Jumlah } \\
\text { Warga } \\
\text { teregister }\end{array}$ & 100 warga & $\begin{array}{l}\text { September } 2015 \\
\text { sd Januari } 2016\end{array}$ & $\begin{array}{l}\text { Total SMS } \\
\text { Terikirim : } \\
1471\end{array}$ & $\begin{array}{l}\text { Database } \\
\text { No HP } \\
\text { masih } \\
\text { terbatas }\end{array}$ & $\begin{array}{l}\text { Pendataan no } \\
\text { HP penduduk } \\
\text { melalul Kepala } \\
\text { Dusu }\end{array}$ \\
\hline \multirow[t]{2}{*}{$\begin{array}{l}\text { C. SMS } \\
\text { gateway } \\
\text { 'pesan } \\
\text { kesehatan' }\end{array}$} & $\begin{array}{l}- \text { Jumlah } \\
\text { sms } \\
\text { terkirim, }\end{array}$ & $\begin{array}{l}-1 \\
\text { sms/minggu } \\
(52 \\
\text { Minggu })\end{array}$ & \multirow[t]{2}{*}{$75 \mathrm{sms}$} & $\begin{array}{l}\text { Screenshoot } \\
\text { pesan }\end{array}$ & $\begin{array}{l}\text { Pesan } \\
\text { Kesehatan } \\
\text { yang masih } \\
\text { minim }\end{array}$ & $\begin{array}{l}\text { Pengumpulan } \\
\text { pesan-pesan } \\
\text { kesehatan } \\
\text { melalui } \\
\text { Departemen \& } \\
\text { Mahasiswa }\end{array}$ \\
\hline & $\begin{array}{l}\text { - Jumlah } \\
\text { penerima } \\
\text { sms }\end{array}$ & $\begin{array}{l}-1000 \\
\text { warga }\end{array}$ & & 75 & & \\
\hline
\end{tabular}

Rekomendasi untuk kegiatan pengabdian masyarakat selanjutnya adalah dibangunnya kesadaran masyarakat akan manfaat dari program yang telah diberikan dan adanya penyesuaian dengan kebiasaan masyarakat. Selain itu diperlukan adanya komunikasi yang intens kepada masyarakat dan evaluasi yang terstruktur. 
DAFTAR PUSTAKA

[1] Badan Pusat Statistik, "Indeks Pembangunan Manusia menurut Kabupaten/Kota, 2016 (mentode Baru)," 2017. [Online]. Available: https://www.bps.go.id/subjek/view/id/26\#subjekViewTab3 . [Diakses 6 November 2017].

[2] B. P. S. K. Sukabumi, “Kecamatan Palabuhanratu dalam Angka 2017," 2017. [Online]. Available:

https://sukabumikab.bps.go.id/index.php/publikasi/index?Publikasi\%5BtahunJudul\%5 D=\&Publikasi\%5BkataKunci\%5D=ratu\&yt0=Tampilkan . [Diakses 6 November 2017]. 


\section{LAMPIRAN}

\section{Foto Kegiatan}

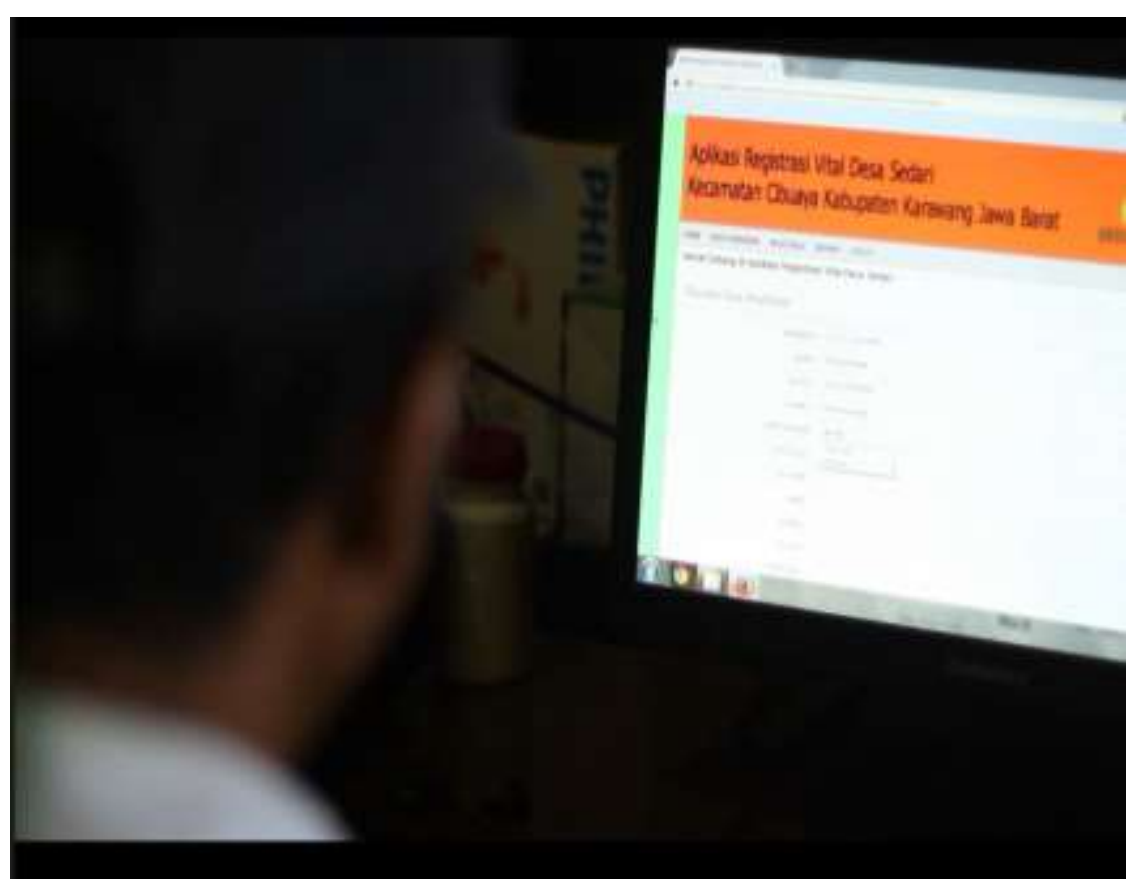

\section{Biodata Narasi Singkat}

Dr. Tris Eryando, drs, MA. Saat ini beliau memangku jabatan sebagai Manajer Riset dan Pengabdian Masyarakat Fakultas Kesehatan Masyarakat Universitas Indonesia dan sebagai staf pengajar di Departemen Biostatistika dan Informatika Kesehatan. Pengalaman beliau sebagai inovator Desa Binaan FKMUI telah dirintis sejak lama saat beliau menjabat sebagai Ketua Lembaga Pengabdian Masyarakat Universitas Indonesia. Kegiatan aktif dalam kegiatan penelitian dan pengabdian masyarakat telah menghasilkan beberapa desa binaan terutama di Provinsi Jawa Barat seperti Karawang dan Sukabumi bekerjasama dengan beberapa pihak swasta (PHE ONWJ) dan pemerintah (BKKBN) sebagai mitra.

Eddy Afriansyah, S.Kom, M.Si. Saat ini bekerja sebagai Kepala Unit Informasi dan Teknologi Fakultas Kesehatan Masyarakat Universitas Indonesia. Kepakaran yang dimiliki oleh beliau adalah sistem informasi, sehingga beliau ahli dalam membuat website dan aplikasi. Beliau juga tergabung ke dalam tim Pengabdian Masyarakat di Desa Sedari, Kabupaten Karawang, Jawa Barat. Telah banyak kegiatan pengabdian masyarakat yang dilakukan oleh beliau. Selain itu beliau juga aktif membuat modul dan saat ini modul tersebut sedang diajukan ke Hak Kekayaan Intelektual (HKI). 
Dr. Dewi Susanna, dra, M.Kes. Beliau adalah dosen di Departemen Kesehatan Lingkungan Fakultas Kesehatan Masyarakat Universitas Indonesia. Beliau aktif dalam bidang penelitian dan pengabdian masyarakat terbukti dengan banyaknya Hibah Pengabdian Masyarakat baik dari Universitas maupun dari DIKTI. Beliau aktif menulis jurnal dan buku serta sebagai pemakalah di berbagai pertemuan baik internasional maupun nasional. Beliau pernah mendapatkan penghargaan sebagai peneliti terbaik rumpun kesehatan di tahun 2010 dan peringkat 3 dosen berprestasi tahun 2011.

Dian Wulandari, SKM, MM. Bekerja sebagai Sekretaris Unit Riset dan Pengabdian Masyarakat (URPM), telah membawa beliau berpengalaman dalam bidang penelitian dan pengabdian masyarakat. Lulusan Sarjana Kesehatan Masyarakat dan Magister Managemen Universitas Indonesia ini memiliki keahlian dalam manajemen lapangan khususnya dalam pengelolaan kegiatan yang berkaitan dengan masyarakat khususnya di bidang kesehatan maupun bidang-bidang yang terkait dengan pembangunan dan pemberdayaan masyarakat. Sebagai pengelola administrasi di bidang penelitian dan pengabdian masyarakat, beliau senantiasa membuat beberapa program sebagai bentuk capaian khususnya kinerja URPM FKMUI tempat beliau bekerja.

Tri Agustini, SKM adalah seorang lulusan Sarjana di Fakultas Kesehatan Masyarakat sejak tahun 2016. Saat ini bekerja sebagai koordinator lapangan dan sekretariat Desa Binaan FKM UI dan mengerjakan beberapa project pengabdian masyarakat. Semasa kuliah pun sudah sering melakukan kegiatan sosial dengan ikut dalam organisasi BEM IM FKM UI di Departemen Sosial Kemasyarakatan. Kepeduliannya tidak hanya di bidang kesehatan, tetapi juga di bidang pendidikan hal ini terlihat dengan ikut terlibat dalam kepanitian tingkat universitas Gerakan UI Mengajar angkatan 4 dan menjadi peserta Kuliah Kerja Nyata $(\mathrm{K} 2 \mathrm{~N})$. 